\title{
Mercury Levels in Raccoons (Procyon Lotor) from the Warta Mouth National Park, Northwestern Poland
}

\author{
Natalia Lanocha • Elzbieta Kalisinska • \\ Danuta I. Kosik-Bogacka • Halina Budis • \\ Joanna Podlasinska $\cdot$ Ewa Jedrzejewska
}

Received: 27 January 2014 / Accepted: 30 March 2014 / Published online: 16 April 2014

(C) The Author(s) 2014. This article is published with open access at Springerlink.com

\begin{abstract}
This is the first report on mercury $(\mathrm{Hg})$ levels in the liver, kidney, skeletal muscle, and brain of raccoon in Europe. It studied Hg concentration in 24 raccoons from the Warta Mouth National Park, northwestern Poland by atomic absorption spectroscopy (AAS). The highest total $\mathrm{Hg}$ concentrations in the raccoon were found in the liver (maximum, $18.45 \mathrm{mg} / \mathrm{kg}$ dry weight), while the lowest in the brain (maximum, $0.49 \mathrm{mg} / \mathrm{kg} \mathrm{dw}$ ). In adult raccoons, $\mathrm{Hg}$ concentrations in the liver, kidney, and brain were higher than in immature individuals $(p<0.001)$, while similar in skeletal muscle in both age groups. Our results are consistent with studies by other authors conducted in North America in areas with similar environmental conditions.
\end{abstract}

Keywords Environmental pollution · Mercury ·

Northwestern Poland · Raccoon

N. Lanocha $\cdot$ E. Kalisinska $\cdot$ D. I. Kosik-Bogacka $(\bowtie) \cdot H$. Budis

Department of Biology and Medical Parasitology, Pomeranian

Medical University, Powstancow Wielkopolskich 72,

70-111 Szczecin, Poland

e-mail: kodan@pum.edu.pl

H. Budis

Department of Health Education, University of Szczecin, Piastow 40B, 71-065 Szczecin, Poland

\section{J. Podlasinska}

Department of Environmental Management and Protection,

Western Pomeranian University of Technology, Słowackiego 17,

71-374 Szczecin, Poland

E. Jedrzejewska

Warta Mouth National Park, Chyrzyno 1, 69-113 Górzyca, Poland

\section{Introduction}

Mercury ( $\mathrm{Hg})$, in addition to lead and cadmium, is considered to be one of the most toxic trace metals. In 2005, global anthropogenic emissions of $\mathrm{Hg}$ to the atmosphere was estimated at 1,930 t, mostly in Asia (over $66 \%$ ), with much less in Europe and North America (8\% each) [1]. The total atmospheric emission of this element in Poland was estimated at almost $16 \mathrm{t}$ in 2007 [2]. Biomagnified along the aquatic trophic chains, mercury reaches its highest concentrations in predatory fish, piscivorous birds, and mammals [3-5]. The estimated biomagnification results in low water $\mathrm{Hg}$ concentrations being multiplied in piscivores by 1 to 10 million times [6].

Mercury, especially methylmercury (MeHg), affects the function and development of the central nervous system in wildlife, resulting in a broad range of adverse health effects such as reproductive and behavioral problems. High $\mathrm{Hg}$ levels can be found in the habitats and food sources of many wildlife species. Mercury poisoning symptoms, mainly motor impairment, have been described in the American mink Neovison vison (Schreber, 1777), the Canadian otter Lontra canadensis (Schreber, 1777), and the red fox Vulpes vulpes (Linnaeus, 1758) [7-9].

Ecotoxicological research on $\mathrm{Hg}$ pollution relies to a great extent on the use of bioindicators. Among the mammals in North America, bioindicators often include local common species as the following: $N$. vison, $L$. canadensis, and the raccoon Procyon lotor (Linnaeus, 1758), while in Europe the native Eurasian otter Lutra lutra (Linnaseus, 1758). An indirect evaluation of $\mathrm{Hg}$ environmental pollution usually involves the determination of $\mathrm{Hg}$ concentration in the soft tissues of the animals, mainly in the liver and kidney [10-13].

The raccoon $P$. lotor, similar to the raccoon dog Nyctereutes procyonoides (Gray, 1834) and the American mink $N$. vison, is one of the most successful alien carnivores 
in Europe [14], being 1 of the 33 alien mammal species that have established self-sustaining populations on the continent [15]. The raccoon was brought to the continent in the 1930s, with feral raccoons in the 1950s and 1960s initiating freeranging populations in Germany, mainly in its central areas and in Brandenburg, a region near the border with Poland [16]. In the 1980s, the raccoon appeared in western Poland, and then a significant influx of its population to Poland was observed in the years 1995-2004, when raccoons were observed near the Odra River in the Szczecin area and in the mouth of the Warta River. By the turn of the century, raccoons had been reported in 15 sites in the central lower Odra Valley and in the lower section of the Warta [17-19].

In contrast to North America, there is no data on $\mathrm{Hg}$ concentrations in the European populations of $P$. lotor, which often inhabits the environment around various water bodies, including large lowland rivers significantly polluted with $\mathrm{Hg}$ and other heavy metals, e.g., from industrial areas, and as such exposed to contaminated food. In North America, the raccoon is considered to be a suitable bioindicator of environmental pollution [20-22]. But so far, this mammal has not been used in Europe as an indicator organism in environmental studies on $\mathrm{Hg}$ pollution. Accordingly, the aim of this study was to determine total $\mathrm{Hg}$ concentrations in liver, kidney, semimembranosus muscle, and brain of raccoons originating from the Warta Mouth National Park (WMNP) in northwestern Poland.

\section{Methods}

The study area was the WMNP $\left(80.7 \mathrm{~km}^{2}\right)$, in the Lubuskie voivodship, western Poland $\left(52^{\circ} 34^{\prime} \mathrm{N}, 14^{\circ} 43^{\prime} \mathrm{E}\right)$. These are floodplains of the lower section of the Warta River and its outlet to the Odra, a fragment of the Odra valley and an area between Kostrzyn and Słońsk, surrounded by flood embankments (Fig. 1). From autumn to spring, $50-100 \%$ of the reservoir is usually flooded, with only small islands and hummocks remaining above the water [23]. The area forms a mosaic of flooded meadows, willow thickets (Salix spp.) and old river beds, shallow lakes, and land improvement canals with overgrown plants [24]. Forests cover only $0.82 \mathrm{~km}^{2}(1 \%$ of the Park's surface area), while arable land and water cover $26.62 \mathrm{~km}^{2}(\sim 33 \%)$ and $2.97 \mathrm{~km}^{2}(\sim 4 \%)$, respectively.

The Odra is the second largest river in Poland, constituting a large section of the Polish-German border. River sediments collected from the Odra and Warta Rivers in the vicinity of Kostrzyn contain elevated levels of heavy metals, including $\mathrm{Hg}[11,25]$. The concentration of $\mathrm{Hg}$ in the sediments of the Odra ranged from 0.25 to $1.49 \mathrm{mg} / \mathrm{kg}$ in Kostrzyn [25]. The main anthropogenic sources of heavy metals (including $\mathrm{Hg}$ ) in the Odra River are the Upper Silesian coal mining and metallurgical district, and the Lower Silesian district (with capital in
Wroclaw) nonferrous (especially copper) metallurgy (between Lubin and Glogow, from 310 to 393 river km). The Odra flows through the following Polish cities: Opole, Wroclaw (266 river km), Kostrzyn (617 river $\mathrm{km}$ ), as well as some German cities, Eisenhuttenstadt (551 river km), Frankfurt (Oder), where major industrial enterprises are located, e.g., the steelworks of the Eisenhuttenkombinat-Ost [26].

This study was carried out on 24 raccoons (P. lotor Linnaeus, 1758), comprising 16 males and 8 females, found dead on the roads of the WMNP between 2009 and 2011. The raccoons were divided into two categories - immature individuals $(n=6)$ and adults $(n=17)$; the age of one individual could not be determined. Even though some organs were damaged, we collected 24 livers, 24 kidneys, 23 semimembranosus muscle (musculus semitendinosus), and 13 brains for chemical analysis. Carcasses were kept at $-20{ }^{\circ} \mathrm{C}$ in a freezer. After dissection of the thawed carcasses, samples (about $10 \mathrm{~g}$ each) used for the determination of $\mathrm{Hg}$ were dried at $55^{\circ} \mathrm{C}[10,11]$. Within 4-6 weeks, the samples were weighed (to $0.1 \mathrm{mg}$, Sartorius BP221S balance) three times to constant weight, which made it possible to determine weight-based sample water content. Subsequently, the samples were crushed in an agate mortar. Total $\mathrm{Hg}$ concentrations were determined using atomic absorption spectroscopy (AAS) at the Department of Environmental Management and Protection, West Pomeranian University of Technology, in Szczecin. The assays were run in an AMA 254 (Altach Ltd, Czech Republic) Hg analyzer in accordance with the procedure described by Kalisinska et al. $[10,11] ; \mathrm{Hg}$ detection limit for this device is about $0.01 \mathrm{ng} \mathrm{Hg}$. The AMA 254 analyzer allowed determination of $\mathrm{Hg}$ in samples without having to perform prior mineralization in wet conditions. The analytical procedures were checked by determining $\mathrm{Hg}$ concentrations in samples of two reference materials - dogfish liver (DOLT-4 Dogfish Liver Certified Reference Material for Trace Metals, Canadian Irradiation Centre, Laval, Quebec) and bovine muscle (Reference Material 8414 Bovine Muscle Powder National Institute of Standards and Technology NIST, Canada). Our analysis of certified reference materials yielded total $\mathrm{Hg}$ concentrations of $2.59 \pm 0.06$ for DOLT- 4 dogfish liver $(n=3)$ and $0.006 \pm 0.0006 \mathrm{mg} / \mathrm{kg}$ dry weight $(\mathrm{dw}) 8414 \operatorname{NIST}(n=5)$. Corresponding values from the suppliers were 2.58 and $0.005 \mathrm{mg} / \mathrm{kg} \mathrm{dw}$, respectively. The recovery rates were 99.6 and $120 \%$ for DOLT- 4 and 8414 NIST, respectively.

Statistical studies were performed using Stat Soft Statistica 9.0 and Microsoft Excel 2007. We calculated the arithmetic means (AM), standard deviations of the AM (SD). The distribution of empirical data on $\mathrm{Hg}$ concentrations in the liver, kidney, muscle and brain diverged from the expected normal distribution, as shown by the Kolmogorov-Smirnov test with Lilliefors correction. Therefore, in comparisons of mean values of $\mathrm{Hg}$ concentration in the examined tissue, and, in order to compare the impact of gender and age, we used 
Fig. 1 Location of study areas in northwestern Poland

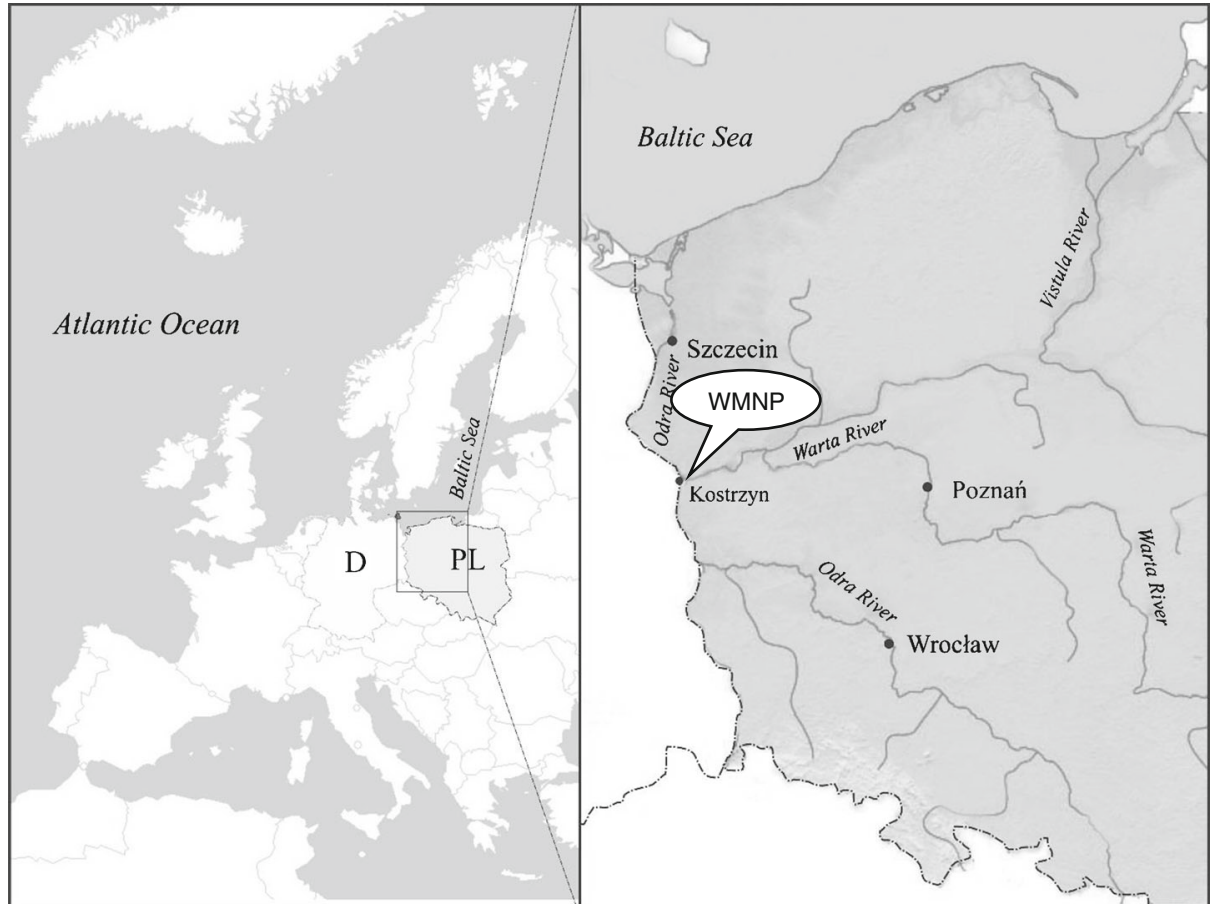

nonparametric Mann-Whitney $U$ tests and Kruskal-Wallis tests $(p<0.05)$.

In addition, the Spearman's rank correlation coefficients $\left(r_{s}\right)$ were determined for the relations between $\mathrm{Hg}$ levels in the materials collected from raccoons (liver, kidney, muscle, and brain) and age categories. Statistical significance was determined at $p<0.05$ for all analyses.

\section{Results}

Mercury concentrations were referred to both dw and wet weight (ww) of the tissue being analyzed. Mean percentages of water content in the liver, kidney, muscle and brain of the raccoon were $70.3 \%, 78.4 \%, 74.6 \%$ and $78.9 \%$, respectively.

Data on $\mathrm{Hg}$ concentrations in the liver, kidney, skeletal muscle and brain of the raccoon are shown in Table 1. The highest mean $\mathrm{Hg}$ concentration was observed in the liver $(2.99 \mathrm{mg} / \mathrm{kg} \mathrm{dw})$ and the lowest in the brain $(0.14 \mathrm{mg} / \mathrm{kg} \mathrm{dw})$. Maximum liver $\mathrm{Hg}$ concentration exceeded $18 \mathrm{mg} / \mathrm{kg} \mathrm{dw}$ in two samples. Similarly, in two cases, liver concentration was in the range of 6 to $10 \mathrm{mg} / \mathrm{kg} \mathrm{dw}$. In the studied materials, $\mathrm{Hg}$ mean concentrations can be arranged in the descending order liver $>$ kidney $>$ muscle $>$ brain. High values of the coefficient of variation (up to $98.3 \%$ for the muscle and $172 \%$ for the liver) reflected significant differences in $\mathrm{Hg}$ concentrations in the examined tissues.

Between adult males $(\mathrm{ad} \mathrm{M})$ and females $(\mathrm{ad} F)$ there were no statistical differences in the $\mathrm{Hg}$ concentrations in the corresponding tissues. Accordingly, immature individuals were combined into one group (im F+im M), similarly to adults (ad $\mathrm{F}+\mathrm{ad} \mathrm{M}$ ). Comparisons of $\mathrm{Hg}$ concentrations in biological materials showed that in the adults $\mathrm{Hg}$ concentrations in the liver $(p<0.001)$, kidney $(p<0.001)$, and brain $(p<0.01)$ were higher than in the immature individuals (Mann-Whitney $U$ test; $p<0.05$ ) (Table 1). In the liver, kidney, and brain, $\mathrm{Hg}$ concentrations in adult raccoons were 53, 19, and 11 times higher than in the immature raccoons, respectively. In the immature and adult raccoons, muscle $\mathrm{Hg}$ concentrations were not statistically significant.

Table 2 presents the results of comparisons between $\mathrm{Hg}$ concentrations in the examined tissues within and between adult and immature groups. The adult group showed differences in $\mathrm{Hg}$ concentrations between most tissues with the exception of the liver vs kidney and muscle vs brain. In the immature group, there was a significant difference in $\mathrm{Hg}$ concentration between kidney and brain $(p<0.05)$. Comparing the immature to adult groups, we found differences in $\mathrm{Hg}$ concentrations between the liver and brain $(p<0.01)$ and between the brain and kidney $(p<0.001)$ (Kruskal-Wallis test; $p<0.05)$.

Analysis of $r_{s}$, which used data from all individuals $(n=$ $24)$, showed that the strongest relationships $\left(r_{s}>0.90\right)$ existed between the liver and kidney $\left(r_{s}=0.98, p<0.001\right)$, liver and brain $\left(r_{s}=0.92, p<0.001\right)$, and the brain and kidney $\left(r_{s}=0.91\right.$, $p<0.001)$. Weaker relationships existed between skeletal muscle and liver $\left(r_{s}=0.52, p<0.01\right)$ and between skeletal muscle and kidney $\left(r_{s}=0.57, p<0.05\right)$.

Additionally, the adult raccoons $(n=17)$ showed statistically significant $(p<0.001)$ and positive correlation coefficients 
Table 1 Total mercury concentrations in liver, kidney, skeletal muscle, and brain of the raccoon age groups and gender (in $\mathrm{mg} / \mathrm{kg}$ $\mathrm{dw}$ ) and differences between $\mathrm{Hg}$ concentration in the examined raccoon tissues in this groups im immature, ad adult, $M$ male, $F$ female, $A M$ arithmetic mean, $S D$ standard deviation, $M e d$ median; $C V$ coefficient of variation in percent, $M-W U$ Mann-Whitney $U$ test, $p$ level of significance, $N S$ difference nonsignificant

\begin{tabular}{|c|c|c|c|c|c|}
\hline \multicolumn{2}{|c|}{$\begin{array}{l}\text { Age or sex group, the number of individuals in each } \\
\text { group }(n) \text { and parameters }\end{array}$} & \multirow{2}{*}{$\begin{array}{l}\text { Liver } \\
6\end{array}$} & \multirow{2}{*}{$\begin{array}{l}\text { Kidney } \\
6\end{array}$} & \multirow{2}{*}{$\begin{array}{l}\text { Muscle } \\
5\end{array}$} & \multirow{2}{*}{$\begin{array}{l}\text { Brain } \\
5\end{array}$} \\
\hline $\mathrm{im}$ & $n$ & & & & \\
\hline & $\mathrm{AM} \pm \mathrm{SD}$ & $0.06 \pm 0.05$ & $0.13 \pm 0.17$ & $0.32 \pm 0.38$ & $0.02 \pm 0.01$ \\
\hline & Med & 0.04 & 0.06 & 0.11 & 0.01 \\
\hline & $\mathrm{CV}$ & 80.4 & 133.6 & 117.0 & 72.2 \\
\hline & Min-max & $0.03-0.15$ & $0.03-0.48$ & $0.01-0.79$ & $0.009-0.04$ \\
\hline \multirow[t]{5}{*}{$\mathrm{ad}$} & $n$ & 17 & 17 & 16 & 8 \\
\hline & $\mathrm{AM} \pm \mathrm{SD}$ & $3.17 \pm 4.66$ & $2.47 \pm 2.43$ & $0.48 \pm 0.45$ & $0.21 \pm 0.18$ \\
\hline & Med & 1.16 & 1.85 & 0.37 & 0.11 \\
\hline & $\mathrm{CV}$ & 146.8 & 98.4 & 93.0 & 84.7 \\
\hline & Min-max & $0.23-18.45$ & $0.37-9.81$ & $0.11-1.67$ & $0.08-0.49$ \\
\hline \multirow[t]{5}{*}{ M } & $n$ & 16 & 16 & 15 & 7 \\
\hline & $\mathrm{AM} \pm \mathrm{SD}$ & $3.08 \pm 4.88$ & $2.24 \pm 2.59$ & $0.45 \pm 0.46$ & $0.14 \pm 0.16$ \\
\hline & Med & 0.83 & 0.98 & 0.21 & 0.10 \\
\hline & $\mathrm{CV}$ & 158.7 & 115.4 & 102.0 & 120.0 \\
\hline & Min-max & $0.03-18.45$ & $0.03-9.81$ & $0.01-1.67$ & $0.01-0.49$ \\
\hline \multirow[t]{5}{*}{$\mathrm{F}$} & $n$ & 8 & 8 & 7 & 6 \\
\hline & $\mathrm{AM} \pm \mathrm{SD}$ & $2.82 \pm 5.98$ & $1.71 \pm 2.41$ & $0.60 \pm 0.58$ & $0.14 \pm 0.19$ \\
\hline & Med & 0.23 & 0.65 & 0.68 & 0.05 \\
\hline & $\mathrm{CV}$ & 212.4 & 140.7 & 95.2 & 138.3 \\
\hline & Min-max & $0.03-17.44$ & $0.03-6.84$ & $0.02-1.64$ & $0.009-0.49$ \\
\hline \multirow[t]{5}{*}{ Total } & $n$ & 24 & 24 & 22 & 13 \\
\hline & $\mathrm{AM} \pm \mathrm{SD}$ & $2.99 \pm 5.14$ & $2.07 \pm 2.50$ & $0.50 \pm 0.49$ & $0.14 \pm 0.17$ \\
\hline & Med & 0.78 & 0.90 & 0.29 & 0.08 \\
\hline & $\mathrm{CV}$ & 172.0 & 120.6 & 98.3 & 123.4 \\
\hline & Min-max & $0.03-18.45$ & $0.03-9.81$ & $0.01-1.67$ & $0.009-0.49$ \\
\hline \multicolumn{6}{|c|}{ im vs ad } \\
\hline $\mathrm{U}$ & & 0 & 1.0 & NS & 0 \\
\hline $\mathrm{P}$ & & 0.001 & 0.001 & & 0.01 \\
\hline \multicolumn{6}{|c|}{ M vs F } \\
\hline $\begin{array}{l}U \\
P\end{array}$ & & NS & NS & NS & NS \\
\hline
\end{tabular}

Table 2 Evaluation of the significance of differences in mercury concentrations between the examined materials collected from raccoons, depending on the age group

\begin{tabular}{lllllll}
\hline K-W & L vs K & L vs M & L vs B & K vs M & K vs B & M vs B \\
\hline $\begin{array}{l}\text { Adultus } \\
p\end{array} \quad \mathrm{NS}$ & 0.01 & 0.001 & 0.01 & 0.0001 & $\mathrm{NS}$ \\
$\begin{array}{l}\text { Immaturus } \\
p \quad \mathrm{NS}\end{array}$ & $\mathrm{NS}$ & $\mathrm{NS}$ & $\mathrm{NS}$ & $\mathrm{NS}$ & 0.04 \\
$\begin{array}{l}\text { Adultus and Immaturus } \\
p\end{array} \quad \mathrm{NS}$ & $\mathrm{NS}$ & 0.01 & $\mathrm{NS}$ & 0.001 & $\mathrm{NS}$ \\
\hline
\end{tabular}

$L$ liver, $K$ kidney, $M$ muscle, $B$ brain, $K W$ Kruskal-Wallis test, $p$ level of significance, $N S$ not significant between liver and kidney $\mathrm{Hg}$ concentrations $\left(r_{s}=0.98\right)$, between kidney and muscle $\mathrm{Hg}\left(r_{s}=0.87\right)$, between liver and brain $\mathrm{Hg}\left(r_{s}=0.96\right)$, and slightly weaker but also significant $(p<0.05)$ correlations between $\mathrm{Hg}$ concentrations in the kidney and brain, muscle and brain (in both cases, $r_{s}=0.81$ ). In the immature raccoons $(n=6)$, there was only one significant relation $(p<0.05)$ - between $\mathrm{Hg}$ concentration in the liver and kidney $\left(r_{s}=0.81\right)$.

A strong relation between $\mathrm{Hg}$ concentrations in the tissues of raccoon was observed also for all the males, i.e., immature and adult $(\mathrm{im}+\mathrm{ad})$ and all females $(\mathrm{im}+\mathrm{ad})$. In males, the highest Spearman's correlation coefficient was found between the $\mathrm{Hg}$ concentrations in the liver and kidney, liver and brain (in both cases: $\left.r_{s}=0.98, p<0.001\right)$, kidney and brain $\left(r_{s}=0.95\right.$, 
$p<0.001$ ), and slightly lower between $\mathrm{Hg}$ concentrations in the liver and muscle, and kidney and muscle $\left(r_{s}=0.65\right.$ and $r_{s}=$ $0.64, p<0.01$, respectively). In the group of females, we found a relation between the kidney and liver $\mathrm{Hg}$ levels $\left(r_{s}=0.98\right.$, $p<0.001)$, as well between the liver and brain $\left(r_{s}=0.90\right.$, $p<0.05$ ).

\section{Discussion}

Raccoons are deemed good bioindicators of environmental contamination, especially in the USA and Canada. As omnivores, they are susceptible to the biomagnification of $\mathrm{Hg}$ due to the consumption of contaminated lower-trophic level organisms from aquatic and terrestrial food chains [20, 22]. Ecotoxicological studies using raccoons, conducted mainly in North America, have most frequently examined the liver and kidney (organs with the main role in detoxification), and less frequently the muscle and brain (Table 3 ).

The availability of $\mathrm{Hg}$ appears to be more associated with river/wetland habitats where methylation processes are enhanced, as seen in the significant differences in Hg levels in raccoons from the river/wetland systems compared to more upland areas [27]. Without comprehensive species- and sitespecific data on $\mathrm{Hg}$ contamination, it is difficult to assess the level of risk to animals inhabiting a particular ecosystem [28]. Based on a review of available literature, the US Fish and Wildlife Service proposed a level of $1.1 \mathrm{mg} / \mathrm{kg}$ ww $(5.5 \mathrm{mg} / \mathrm{kg}$ $\mathrm{dw}$ ) for liver, kidney, blood, and hair in wild mammals that "should be considered as presumptive evidence of an environmental mercury problem" [3].

Levels of exposure that induce $\mathrm{Hg}$ poisoning in mammals vary among species. Threshold $\mathrm{Hg}$ concentrations for the raccoon (accumulation resulting from the geochemical background) have not yet been established, likewise sublethal and lethal concentrations. Laboratory tests and observations conducted on the domestic dog (Canis familiaris) show that typical $\mathrm{Hg}$ levels (reflecting their geochemical background) in the liver and kidney of this domesticated mammal are $<0.1 \mathrm{mg} / \mathrm{kg}$ ww $(\sim 0.3 \mathrm{mg} / \mathrm{kg} \mathrm{dw})$ and lethal $\mathrm{Hg}$ concentration to these organs are at 2.8 and $3.3 \mathrm{mg} / \mathrm{kg}$ ww $(9.3$ and $11 \mathrm{mg} / \mathrm{kg}$ $\mathrm{dw})$, respectively [29]. In the examined raccoon from WMNP Poland, the concentrations of $\mathrm{Hg}$ in the kidney and liver were approximately 10 and 7 times higher than the values reflecting the domestic geochemical background suggested by Farrar et al. [29].

\section{Mercury in Liver and Kidney}

The liver is the major site of MeHg biotransformation. In raccoons from the Everglades National Park, Hg concentrations in the liver were more than 18 times higher than in individuals from NW Poland [21] (Table 3). Elevated concentrations of this element in the late 1980s and 1990s in many animals from the Everglades were associated with air pollution from metal mining and smelting, coal-fired utilities and industry, and solid-waste incinerators [30, 31].

Mercury concentrations in the liver in the examined raccoons living in the Warta Mouth National Park in northwestern Poland ranged from 0.03 to $18.45 \mathrm{mg} / \mathrm{kg} \mathrm{dw}$ (mean, $2.99 \mathrm{mg} / \mathrm{kg} \mathrm{dw}$ ), with the concentrations of four specimens considered elevated $(>5.5 \mathrm{mg} / \mathrm{kg} \mathrm{dw})$. The results do not indicate a risk of death from acute $\mathrm{Hg}$ intoxication as the measured levels were not even close to the $125 \mathrm{mg} / \mathrm{kg} \mathrm{dw}$ $(25 \mathrm{mg} / \mathrm{kg} \mathrm{ww}$ ) reported in kidneys of carnivorous mammals, the level associated with lethal mercury poisoning [32].

The kidney may also play a role in the demethylation of $\mathrm{MeHg}$, accounting for the high inorganic $\mathrm{Hg}$ concentrations in the kidney (55 \%). High inorganic $\mathrm{Hg}$ in the liver and kidney relative to other tissues has also been reported for the river otter and the wild mink [33, 34]. Based on publications, kidney $\mathrm{Hg}$ concentrations in the North American raccoons range from 1.2 to $6.8 \mathrm{mg} / \mathrm{kg} \mathrm{dw}$. In individuals from the WMNP Hg concentration was generally low, with more than $54 \%$ of the cases not exceeding $1 \mathrm{mg} / \mathrm{kg} \mathrm{dw}$, and concentration ranges of $1-4$ and $>5 \mathrm{mg} / \mathrm{kg} \mathrm{dw}$ accounted for 30 and $16 \%$ of the samples, respectively.

Biomonitoring studies using raccoons have been carried out in the Shiawassee National Wildlife Refuge (SNWR) in Canada [35]. In the SNWR, raccoons were acquired from the backwaters of rivers flowing through the Refuge, the quality of which is generally poor. Most of the rivers also pass through cities, heavily industrialized areas, and agricultural land, and therefore are exposed to industrial and wastewater discharge, and agricultural runoff. Mercury concentrations in the liver, muscle, and brain tissues in raccoons from the Canadian Refuge and the Warta River Mouth National Park, Poland were similar, and in both cases the $\mathrm{Hg}$ concentration in adults was greater in adults than in young individuals. Comparison of $\mathrm{Hg}$ concentrations in the liver, kidney, and brain tissues of raccoons from the SNWR in Canada [35] between the two age categories (immatures and adults) showed a relation similar to that observed in individuals from the WMNP in Poland. The mercury concentrations in the studied organs were higher in adults than in young individuals. Mercury levels in the kidney in adults from Canada were lower than levels reported in this research. The results from this study are consistent with those reports that indicate the liver and kidney as the major storage sites for $\mathrm{Hg}$ in raccoons, followed by the muscle and brain. Furthermore, they also confirm the age-related upward trend in the concentration of toxic metals in the liver and kidney of raccoons. In raccoons from NW Poland, similar to raccoons from Alabama in the USA [36] and the SNWR in Canada [35], Hg concentration in the liver and kidney did not show any significant differences between genders. High $\mathrm{Hg}$ concentrations in the kidney and 
Table 3 Comparison of mean mercury concentrations in the liver, kidney, muscle, and brain of raccoon from Poland and North America (mg/kg dw and ww; in the dw and ww conversions, it was found that both the liver and muscle contained $70 \%$ water and the kidney and brain contained $80 \%$ water)

\begin{tabular}{|c|c|c|c|c|c|c|c|}
\hline Liver (L) & Kidney (K) & Muscle (M) & Brain (B) & Dry/wet weight & Number $(n)$ & Country & Source \\
\hline 2.99 & 2.07 & 0.50 & 0.14 & $\mathrm{dw}$ & \multirow[t]{2}{*}{24} & \multirow[t]{2}{*}{ Poland, WMNP } & \multirow[t]{2}{*}{ this study } \\
\hline 0.90 & 0.41 & 0.15 & 0.03 & ww & & & \\
\hline- & - & 0.43 & - & $\mathrm{dw}$ & \multirow[t]{2}{*}{$3 \mathrm{M}$} & \multirow{2}{*}{$\begin{array}{l}\text { USA, Georgia, } \\
\text { Piedmont }\end{array}$} & \multirow[t]{8}{*}[40]{} \\
\hline- & - & 0.13 & - & ww & & & \\
\hline 7.8 & - & 0.73 & - & $\mathrm{dw}$ & \multirow[t]{2}{*}{$6 \mathrm{~L} / 6 \mathrm{M}$} & \multirow[t]{2}{*}{ USA, Upper Coastal } & \\
\hline 2.34 & - & 0.22 & - & ww & & & \\
\hline 4.77 & - & 0.93 & - & $\mathrm{dw}$ & \multirow[t]{2}{*}{$4 \mathrm{~L} / 22 \mathrm{M}$} & \multirow[t]{2}{*}{ USA, Lower Coastal } & \\
\hline 1.43 & - & 0.28 & - & ww & & & \\
\hline 15.1 & - & 1.3 & - & $\mathrm{dw}$ & \multirow[t]{2}{*}{$4 \mathrm{~L} / 5 \mathrm{M}$} & \multirow[t]{2}{*}{ USA, SCSRS } & \\
\hline 4.53 & - & 0.39 & - & ww & & & \\
\hline 4.5 & 5.47 & 1.1 & - & $\mathrm{dw}$ & \multirow[t]{4}{*}{95} & \multirow[t]{2}{*}{ USA, SCSRS: Steel Creek delta } & \multirow[t]{2}{*}[20]{} \\
\hline 1.35 & 1.64 & 0.33 & - & ww & & & \\
\hline 23.4 & \multirow[t]{2}{*}{-} & \multirow[t]{2}{*}{-} & 2.1 & $\mathrm{dw}$ & & \multirow[t]{2}{*}{ USA, California } & \multirow[t]{2}{*}[57]{} \\
\hline 7.02 & & & 0.63 & ww & & & \\
\hline 1.37 & 1.20 & & & $\mathrm{dw}$ & \multirow[t]{2}{*}{15} & \multirow[t]{2}{*}{ USA, Macon Country, Alabama } & \multirow[t]{2}{*}[36]{} \\
\hline 0.41 & 0.24 & - & - & ww & & & \\
\hline 4.43 & - & - & - & $\mathrm{dw}$ & \multirow[t]{2}{*}{47} & \multirow[t]{2}{*}{ USA, SRS } & \multirow[t]{2}{*}[58]{} \\
\hline 1.33 & - & - & - & ww & & & \\
\hline 4.83 & 3.93 & - & - & $\mathrm{dw}$ & \multirow[t]{2}{*}{70} & USA, SRS & {$[42]$} \\
\hline 1.45 & 1.18 & - & - & ww & & & \\
\hline 28.2 & - & - & - & $\mathrm{dw}$ & 4 & USA, SRS & {$[27]$} \\
\hline 8.46 & - & - & - & ww & & NWR, Hutchinson Island & \\
\hline 7.2 & - & - & - & $\mathrm{dw}$ & 3 & & \\
\hline 2.16 & - & - & - & ww & & Control site & \\
\hline 54.0 & 5.0 & 1.9 & 0.96 & $\mathrm{dw}$ & 11 & USA, South Florida & {$[21]$} \\
\hline 16.2 & 1.49 & 0.57 & 0.29 & ww & & Everglades & \\
\hline $0.12-0.68$ & $0.25-1.95$ & - & - & $\mathrm{dw}$ & 16 & USA, Central New York & {$[38]$} \\
\hline $0.04-0.21$ & $0.05-0.39$ & & & ww & & & \\
\hline 6.7 & 6.8 & - & - & $\mathrm{dw}$ & & USA, Wisconsin & {$[37]$} \\
\hline 2.01 & 1.37 & & & ww & & & \\
\hline 13.66 & - & 2.44 & - & $\mathrm{dw}$ & 5 & USA, Texas and Louisiana & [59] \\
\hline 4.1 & & 0.73 & & ww & & & \\
\hline- & 0.055 & - & 0.575 & $\mathrm{dw}$ & 10 & USA, Emory River, East Tennnessee & {$[22]$} \\
\hline- & 0.115 & - & 0.011 & ww & & & \\
\hline 15.1 & 3.7 & 0.93 & - & $\mathrm{dw}$ & 4 & Canada, Georgia Bay & [9] \\
\hline 4.53 & 1.11 & 0.28 & & ww & & & \\
\hline 3.93 & 1.35 & - & 0.13 & $\mathrm{dw}$ & 25 & Canada, SNWR & {$[35]$} \\
\hline 1.18 & 0.27 & & 0.04 & ww & & & \\
\hline
\end{tabular}

WMNP Warta Mouth National Park, SNWR Shiawassee National Wildlife Refuge, SCSRS South Carolina Savannah River Site

liver of raccoons (6.8 and $6.7 \mathrm{mg} / \mathrm{kg} \mathrm{dw}$, respectively) were found by Sheff and Amant [37]. Although those studies were conducted in uncontaminated sites near Wisconsin, they were located in areas where $\mathrm{Hg}$ occurs naturally at high levels in soil and rock.

In most cases, liver and kidney $\mathrm{Hg}$ levels in raccoon from Poland were lower than those found in the USA and Canada (Table 3), at approximately 3 and $2 \mathrm{mg} / \mathrm{kg} \mathrm{dw}$. However, they were greater than in the population of Central NY and Macon Country, Alabama (USA) [36, 38].

Our previous studies carried out in the Warta Mouth National Park [11] showed that Hg concentrations in the liver and kidney in American mink ( $N$. vison) were 11.8 and $14.1 \mathrm{mg} / \mathrm{kg}$ $\mathrm{dw}$, almost four and seven times higher than in the raccoon in this study, respectively. These significantly higher liver and kidney $\mathrm{Hg}$ concentrations in mink compared to raccoon in the same area are probably related to differences in the diet of the animals. Raccoons in the WMNP eat mainly small mammals (primarily rodents), which account for $40 \%$ of their diet, while fish and amphibians comprise only $13 \%$. The American mink is a very piscivorous species - in the WMNP its diet also includes piscivorous birds [17]. According to a study by Kucera [39], the American mink occupies a top trophic position in the aquatic foodweb and bioaccumulates $\mathrm{Hg}$ from 
food, about 10 times more $\mathrm{Hg}$ on a concentration basis than predatory fish from the same drainage areas.

\section{Mercury in Muscle}

In studies conducted in different regions of the eastern USA, it was found that muscle $\mathrm{Hg}$ levels were the lowest in Piedmont raccoons $(0.43 \mathrm{mg} / \mathrm{kg} \mathrm{dw})$, higher in raccoons from the Upper Coastal Plain $(0.73 \mathrm{mg} / \mathrm{kg} \mathrm{dw})$ and the highest in Lower Coastal Plain raccoons $(0.93 \mathrm{mg} / \mathrm{kg} \mathrm{dw})$ [40]. However, the highest $\mathrm{Hg}$ concentration those authors reported in raccoons from the US Atomic Energy Commission Savannah River Site (SRS) in South Carolina was in skeletal muscle and the liver, 1.3 and $15.1 \mathrm{mg} / \mathrm{kg} \mathrm{dw}$, respectively. Compared to the SRS, Hg concentrations in the liver and muscle of WMNP raccoons were five and two times lower, respectively, which may result from the significant industrial $\mathrm{Hg}$ pollutant in the said part of the SRS. The nearby Savannah River flows below the principal sources of $\mathrm{Hg}$ at Augusta, Georgia, and was used for atomic reactor cooling at the SRS. During the past 50 years, $\mathrm{Hg}$ and other contaminants have been released into the SRS environment from various sources [41]. That region had been used for nuclear weapons production, and in the past levels of several toxic elements, including $\mathrm{Hg}$ in water, were considerably excessive [42], as is shown in numerous reports on raccoons [20, 27, 40, 43]. In addition, the diet of North American and Canadian raccoons is rich in fish, frogs, and birds which may contain significant amounts of $\mathrm{Hg}$ [44].

In contrast to Europe, the North American raccoon is hunted not only for its fur but also for its meat. Therefore, a significant part of the raccoon carcass is a potential source of $\mathrm{Hg}$ (in muscle mainly as $\mathrm{MeHg}$ ), toxic to humans, predatory and scavenging birds, and mammals [45]. For these reasons, it is reasonable to determine $\mathrm{Hg}$ in raccoon muscle, especially in ecotoxicological studies. Mean Hg concentrations in the muscle of raccoons in North American areas slightly contaminated with $\mathrm{Hg}$ are less than $1 \mathrm{mg} / \mathrm{kg} \mathrm{dw}(0.4-0.9 \mathrm{mg} / \mathrm{kg} \mathrm{dw}$; Table 3$)$. The highest $\mathrm{Hg}$ concentrations $(\sim 2 \mathrm{mg} / \mathrm{kg} \mathrm{dw})$ were recorded in the muscles of the raccoon from Caddo Lake (Texas and Louisiana, USA) and Everglades Park, which resulted from a significant $\mathrm{Hg}$ pollution (Table 3).

\section{Mercury in Brain}

Organic and inorganic $\mathrm{Hg}$ compounds easily permeate the blood-brain barrier [46, 47]. Although $\mathrm{Hg}$ toxicity primarily affects the nervous system, environmental analyses seldom concern $\mathrm{Hg}$ in mammalian brains [5]. However, in some reports, the brains of rats experimentally exposed to incremental doses of Hg showed increasing pathomorphological changes, including vascular lesions, disappearance and demyelination of neurons, necroses in the cerebellum cortex and brain stem nuclei, and atrophy and abnormal density of granulosa cells of the cerebellum [48-50]. Moreover, Basu et al. [51] observed significant neurochemical changes in wild mink, although brain THg (total mercury) levels were low, 0.11 to $13.4 \mathrm{mg} / \mathrm{g}$ ww $(0.22-26.8 \mathrm{mg} / \mathrm{g} \mathrm{dw})$, i.e., below the concentrations that may cause adverse effects as proposed by the US EPA [52].

Out of 13 papers concerning field studies on raccoons in North America, only 4 included information on Hg concentration in the brain. In individuals from the WMNP in Poland, brain $\mathrm{Hg}$ concentration was low $(0.14 \mathrm{mg} / \mathrm{kg} \mathrm{dw})$, much less than the low limit given by Basu et al. [51]. In raccoons from different parts of North America, reported mean brain $\mathrm{Hg}$ concentrations are generally higher than in Poland and range from 0.13 to $2.1 \mathrm{mg} / \mathrm{kg} \mathrm{dw}$ (Table 3 ). The highest $\mathrm{Hg}$ concentrations were found in the brain of raccoon from California, more than 15 times higher than in the WMNP. However, Souza et al. [22] found a more than two times lower $\mathrm{Hg}$ concentration in the brain of raccoon in East Tennessee, in an area exposed to coal fly ash (Table 3), where more than five million cubic yards of coal fly ash and water spilled into the Emory River in 2008, significantly polluting it with oxides of silicon, aluminum, iron, and trace elements [53]. Low Hg concentration in the brain of raccoons could have resulted from the fact that the coal fly ash had limited amounts of $\mathrm{Hg}$ and other hazardous metals.

\section{Toxicity}

In animals, the effects of $\mathrm{Hg}$ toxicity are manifested by reduced reproductive success associated with embryo mortality and, in particular, damage to the central nervous system including the cerebellum, ataxia and paresthesia, described in literature as the "dancing cats" illness. Among raccoons, $\mathrm{Hg}$ poisoning is very rare. However, fatal $\mathrm{Hg}$ poisonings have been described in panthers (Puma concolor coryi) from the Florida Everglades, Shark River Slough [54]. The normal diet of panthers from the Everglade Park comprises deer and wild hog, but raccoons may also become a major component of the panther's diet. Roelke [54] reported that raccoons from the same area had $\mathrm{Hg}$ levels from 10 to 100 times greater than deer. It was found that $\mathrm{Hg}$ concentration in the liver of dead panther ranged from 26 and $110 \mathrm{mg} / \mathrm{kg}$ ww. In comparison, Charbonneau et al. [55] reported that cats chronically fed with lethal concentrations of $\mathrm{MeHg}$ had mean total $\mathrm{Hg}$ concentrations in the liver ranging from 38 to $92 \mathrm{mg} / \mathrm{kg}$ ww. These elevated $\mathrm{Hg}$ levels in panthers have been correlated with elevated levels of total $\mathrm{Hg}$ in their prey; raccoons, and alligators [31, 54]. Mercury levels found in the muscle of raccoons from the greater Shark River Slough area were well above $1.0 \mathrm{mg} / \mathrm{kg}$ ww (range, $1.01-1.80 \mathrm{mg} / \mathrm{kg} \mathrm{ww}$ ) and were significantly higher $(p<0.05)$ than in raccoons from other areas examined [56]. The accumulation of $\mathrm{Hg}$ in raccoons largely depends on diet, especially the portion of fish, as documented 
in several cases. Raccoons in the same area as the panthers in Florida had nine times greater $\mathrm{Hg}$ concentrations in their muscle than individuals from the WMNP.

\section{Sensitivity}

Comparing $\mathrm{Hg}$ concentrations in the organs and tissues of raccoons from northwestern Poland, the highest was found in the liver, lower in the kidney and muscle, and the lowest in the brain. These observations are consistent with data of other authors on the content and distribution of this element in the raccoon from North America and Canada (Table 3). For example, Porcella et al. [21] observed that raccoon in North America had $\mathrm{Hg}$ concentration in the liver greater than in the kidney. Similarly, Wren et al. [28] noted that the Hg concentration in the liver of raccoons from Georgia Bay in Canada was four times higher than in the kidneys.

Scant existing publications on $\mathrm{Hg}$ concentrations in the raccoon have described relations between concentrations of this metal determined in various animal tissues. Lord et al. [20] found a correlation between the concentrations of $\mathrm{Hg}$ in the liver and kidney, and the liver and muscle $(r=0.60)$. Porcella et al. [21] documented the existence of a stronger relationship between the liver and kidney $(r=0.71)$, suggesting that the liver is the source of $\mathrm{Hg}$ to the kidney or that the kidney demethylates $\mathrm{MeHg}$ as well. Analysis of our results showed the existence of strong relations between $\mathrm{Hg}$ concentrations in the liver and kidney, liver and brain, and brain and kidney $\left(r_{s} \approx 0.90\right)$, and weaker between $\mathrm{Hg}$ concentrations in the liver and muscle, and kidney and muscle $\left(r_{s} \approx 0.50\right)$.

Our study is analogous to some investigations in North America that have been conducted for many years. Our results on raccoons living near a large Polish river were similar to reports by Lord et al. [20] and Souza et al. [22] who also investigated raccoons living in riparian areas with relatively low Hg pollution. In other parts of North America, with higher $\mathrm{Hg}$ contamination, raccoons showed high $\mathrm{Hg}$ concentrations.

Acknowledgments The Pomeranian Medical University in Szczecin provided financial support. The authors would especially like to thank the employees of the Warta Mouth National Park for the collection of material.

Open Access This article is distributed under the terms of the Creative Commons Attribution License which permits any use, distribution, and reproduction in any medium, provided the original author(s) and the source are credited.

\section{References}

1. AMAP/UNEP (2008) Technical background report to the global atmospheric mercury assessment. Arctic Monitoring and Assessment Programme/UNEP Chemicals Branch, pp 1-159
2. Debski B, Olendrzynski K, Cieslinska J, Kargulewicz I, Skoskiewicz J, Olecka A, Kania K (2009) Air emission inventory of $\mathrm{SO}, \mathrm{NO}, \mathrm{NH}$, ashes, heavy metals, NMVOC and POP in Poland in year 2007, KASHUE. Environmental Protection Institute, Warsaw, pp 1-92

3. Eisler R (2000) Handbook of chemical assessment: health hazards to humans, plants and animals, vol I. Lewis, Washington, DC, USA

4. Scheuhammer AM, Meyer MW, Sandheinrich MB, Murray MW (2007) Effects of environmental methylmercury on health of wild birds, mammals, and fish. Ambio 36:12-18

5. Wiener JG, Krabbenhoft DP, Heinz GH, Scheuhammer AM (2003) Ecotoxicology of mercury. In: Hoffman DJ, Rattner BA, Burton GA, Cairns J (eds) Handbook of ecotoxicology. Lewis, Boca Raton, pp 409-463

6. Driscoll CT, Han YJ, Chen C, Evers DC, Lambert KF, Holsen TM, Kamman NC, Munson RK (2007) Mercury contamination in forest and freshwater ecosystems in the northeastern United States. Bioscience 57:1-28

7. Borg K, Wanntorp H, Erne K, Hanko E (1969) Alkyl mercury poisoning in terrestrial Swedish wildlife. Viltrevy 6:301-379

8. Wobeser G, Nielsen NO, Schiefer B (1976) Mercury and mink. II. Experimental methyl mercury intoxication. Can J Com Med 40:34 45

9. Wren C, MacCrimmon H, Frank R, Suda P (1980) Total and methyl mercury levels in wildlife mammals from the PreCambrian Shield area of south central Ontario Canada. Bull Environ Contam Toxicol 25:100-105

10. Kalisinska E, Lisowski P, Salicki W, Kucharska T, Kavetska K (2009) Mercury in wild terrestrial carnivorous mammals from north-western Poland and unusual fish diet of red fox. Acta Theriol 54:345-356

11. Kalisinska E, Budis H, Lanocha N, Podlasinska J, Jedrzejewska E, Kosik-Bogacka DI (2012) Comparison of hepatic and nephric total mercury concentrations between feral and ranch American mink (Neovison vison) from northwestern Poland. Bull Environ Contam Toxicol 88:802-806

12. Millan J, Mateo R, Taggart MA, Lopez-Bao JV, Viota M, Monsalve L, Camarero PR, Blazquez E, Jimenez B (2008) Levels of heavy metals and metalloids in critically endangered Iberian lynx and other wild carnivores from Southern Spain. Sci Total Environ 399:193-201

13. Reglero MM, Monsalve-Gonzalez L, Taggart MA, Mateo R (2008) Transfer of metals to plants and red deer in an old lead mining area in Spain. Sci Total Environ 144:191-199

14. Kauhala K, Kowalczyk R (2011) Invasion of the raccoon dog Nyctereutes procyonoides in Europe: history of colonization, features behind its success, and threats to native fauna. Curr Zool 57:584-598

15. Genovesi P, Carnevali L, Alonzi A, Scalera R (2012) Alien mammals in Europe: updated numbers and trends, and assessment of the effects on biodiversity. Integr Zool 7:247-253

16. Beltran-Beck B, Garcia FJ, Gortazar C (2012) Raccoons in Europe: disease hazards due to the establishment of an invasive species. Eur J Wildl Res 58:5-15

17. Bartoszewicz M, Okarma H, Zalewski A, Szczęsna J (2008) Ecology of the raccoon (Procyon lotor) from western Poland. Ann Zool Fennici 45:291-298

18. Bartoszewicz M, Zalewski A (2003) American mink, Mustela vison diet and predation on waterfowl in the Słonsk Reserve, western Poland. Folia Zool 52:225-238

19. Hohmann U, Gerhard R, Kasper M (2000) Home range size of adult raccoons (Procyon lotor) in Germany. Z Säugetierk 65:124-127

20. Lord CG, Gaines KF, Boring CS, Brisbin IL Jr, Gochfeld M, Burger J (2002) Raccoon (Procyon lotor) as a bioindicator of mercury contamination at the U.S. Department of Energy's Savannah River Site. Arch Environ Contam Toxicol 43:356363 
21. Porcella DB, Zillioux EJ, Grieb TM, Newman JR, West GB (2004) Retrospective study of mercury in raccoons (Procyon lotor) in south Florida. Ecotoxicology 13:207-221

22. Souza MJ, Ramsay EC, Donnell RL (2013) Metal accumulation and health effects in raccoons (Procyon lotor) associated with coal fly ash exposure. Arch Environ Contam Toxicol 64:529-536

23. Zalewski A, Bartoszewicz M (2012) Phenotypic variation of an alien species in a new environment: the body size and diet of American mink over time and at local and continental scales. Biol J Linn Soc 105:681-693

24. Bartoszewicz M, Okarma H, Szczęsna J, Zalewski A (2008) Ecology of raccoon (Procyon lotor L. 1758) from western Poland. Ann Zool Fennici 45:291-298

25. Boszke L, Sobczynski T, Glosinska D, Kowalski A, Siepak J (2004) Distribution of mercury and other heavy metals in bottom sediments of middle part Odra River (Germany/Poland). Pol J Environ Stud 13:495502

26. Muller A, Heininger P, Wessels M, Pelzer J, Grunwald K, Pfitzner S, Berger M (2002) Contaminant levels and ecotoxicological effects in sedimentation of the River Odra. Acta Hydrochim Hydrobiol 30: 244-255

27. Winger PV, Lasier PJ, White DH, Seginak JT (2000) Effects of contaminants in dredge material from the lower Savannah River. Arch Environ Contam Toxicol 38:128-136

28. Wren CD (1984) Distribution of metals in tissues of beaver, raccoon, and otter from Ontario, Canada. Sci Total Environ 34:177-184

29. Farrar WP, Edwards JF, Willard MD (1994) Pathology in a dog associated with elevated tissue mercury concentrations. J Vet Diagn Invest 6:511-514

30. Axelrad DM, Gabriel M, Lange T (2011) Chapter 3B: Mercury monitoring, research and environmental assessment in South Florida. In: Redfield G (ed) 2010 South Florida Environmental Report-volume I. South Florida Water Management District, West Palm Beach, FL

31. Newman J, Zillioux E, Rich E, Liang L, Newman C (2004) Historical and other patterns of monomethyl and inorganic mercury in the Florida panther (Puma concolor coryi). Arch Environ Contam Toxicol 48:75-80

32. Beyer NW, Meador JP (eds) (2011) Environmental contaminants in biota: interpreting tissue concentrations. Taylor and Francis, Boca Raton, FL

33. Evans RD, Addison EM, Villeneuve JY, MacDonald KS, Joachim DG (2000) Distribution of inorganic and methylmercury among tissues in mink (Mustela vison) and otter (Lutra canadensis). Environ Res 84:133-139

34. Fortin C, Beauchamp G, Dansereau M, Lariviere N, Belanger D (2001) Spatial variation in mercury concentrations in wild mink and river Otter carcasses from the James bay territory, Quebec, Canada. Arch Environ Contam Toxicol 40:121-127

35. Herbert GB (1988) A survey of xenobiotics on the Shiawassee National Wildlife Refuge, Michigan. Masters Thesis. The Ohio State University, Columbus, Ohio, p 98

36. Khan AT, Thompson SJ, Mielke HW (1995) Lead and mercury levels in raccoons from Macon County, Alabama. Bull Environ Contam Toxicol 54:812-816

37. Sheff TB, Amant S Jr (1982) Mercury burdens in furbearers in Wisconsin. J Wildl Manage 46:1117-1120

38. Valentine RL, Bache CA, Gutenmann WH, Lisk DJ (1988) Tissue concentrations of heavy metals and polychlorinated biphenyls in raccoons in Central New York. Bull Environ Contam Toxicol 40:711-716

39. Kucera E (1983) Mink and otter as indicators of mercury in Manitoba waters. Can J Zool 61:2250-2256

40. Cumbie PM, Jenkins JH (1974) Mercury accumulation in native mammals of the southeast. In: Proceedings of the 28th Annual Conference of the Southeastern Association of Game and Fish Commissioners, pp 639-648
41. Sugg DW, Chesser RK, Brooks JA, Grasman BT (1995) The association of DNA damage to concentrations of mercury and radiocesium in largemouth bass. Environ Toxicol Chem 14:661-668

42. Burger J, Gaines KF, Lord CG, Brisbin IL Jr, Shukla S, Gochfeld M (2002) Metal levels in raccoon tissues: differences on and off the Department of Energy's Savannah River Site in South Carolina. Environ Monit Assess 74:67-84

43. Burger J, Gaines KF, Gochfeld M (2001) Ethnic differences in risk from mercury among Savannah River fishermen. Risk Anal 21:533-544

44. Azevedo FCC, Lester V, Gorsuch W, Lariviere S, Wirsing AJ, Murray DL (2006) Dietary breadth and overlap among five sympatric prairie carnivores. J Zool 269:127-135

45. Horvat M, Nolde N, Fajon V, Jereb V, Logar M, Lojen S, Jacimovic R, Falnoga I, Liya Q, Faganeli J, Drobne D (2003) Total mercury, methylmercury and selenium in mercury polluted areas in the province Guizhou, China. Sci Total Environ 304:231-256

46. Davis LE, Kornfeld M, Mooney HS, Fiedler KJ, Haaland KY, Orrison WW, Cernichiari E, Clarkson TW (1994) Methylmercury poisoning: long-term clinical, radiological, toxicological, and pathological studies of an affected family. Ann Neurol 35:680-688

47. Graeme KA, Pollack CV Jr (1998) Heavy metal toxicity, Part I: arsenic and mercury. J Emerg Med 16:45-56

48. Madej JA, Zechalko A, Szymczak J, Biernat J (1985) Effect of calcium deficiency on histopathological changes and accumulation of metals in the brain of rats in a comprehensive lead poisoning, cadmium and mercury. Bromatol Chem Toksykol 18:173-180

49. Nagashima K (1997) A review of experimental methylmercury toxicity in rats: Neuropathology and evidence for apoptosis. Toxicol Pathol 25:624-631

50. Nagashima K, Fujii Y, Tsukamoto T, Nukuzuma S, Satoh M, Fujita M, Fujioka Y, Akagi H (1996) Apoptotic process of cerebellar degeneration in experimental methylmercury intoxication of rats. Acta Neuropathol 91:7277

51. Basu N, Klenavic K, Gamberg M, O'Brien M, Evans D, Scheuhammer AM, Chan HM (2005) Effects of mercury on neurochemical receptor-binding characteristics in wild mink. Environ Toxicol Chem 24:1444-1450

52. United States Environmental Protection Agency (1997) Mercury study report to Congress. Vol. VI. IN: An ecological assessment for anthropogenic mercury emissions in the United States. USEPA-452/R-97-008

53. Patra KC, Rautray TR, Tripathy BB, Nayak P (2012) Elemental analysis of coal and coal ASH by PIXE technique. Appl Radiat Isot 70:612-616

54. Roelke ME, Schultz DP, Facemire CF, Sundlof SF, Royals HE (1991) Mercury contamination in Florida panthers. Florida Panther Technical Subcommittee, Florida Game and Fresh Water Fish Commission, Tallahassee, Florida, p 50

55. Charbonneau SM, Munrow IC, Nera EA, Armstrong FAJ (1976) Chronic toxicity in methylmercury in the adult cat. In: Trace substances in environmental health-X. A symposium. University of Missouri, Columbia, MO, USA, pp 435-439

56. Dunbar MR (1993) Florida panther biomedical investigation. Annual performance report, July 1, 1992 to June 30, 1993. Study no. 7506. Florida Game and Fresh Water Fish Commission, Tallahassee, Florida

57. Wolfe M, Norman D (1998) Effects of waterborne mercury on terrestrial wildlife at Clear Lake: evaluation and testing of a predictive model. Environ Toxicol Chem 17:214-227

58. Burger J, Lord CG, Yurkow EJ, McGrath L, Gaines KF, Brisbin IL Jr, Gochfeld M (2000) Metals and metallothionein in the liver of raccoons: utility for environmental assessment and monitoring. $\mathrm{J}$ Toxicol Environ Health A 60:243-261

59. Chumchal MM, Rainwater TR, Osborn SC, Roberts AP, Abel MT, Cobb GP, Smith PN, Bailey FC (2011) Mercury speciation and biomagnification in the food web of Caddo Lake, Texas and Louisiana, USA, a subtropical freshwater ecosystem. Environ Toxicol Chem 30:1153-1162 